\title{
Innovative Techniques to Develop Educative Competitiveness in Adolescents' Mental Health: Importance in Nursing Training
}

\author{
Paloma Carapia-Fierros1, Diana Cecilia Tapia-Pancardo ${ }^{2 *}$ \\ ${ }^{1}$ Carrera de Enfermería, Facultad de Estudios Superiores Iztacala, Universidad Nacional Autónoma de México, Tlalnepantla, \\ México \\ ${ }^{2}$ División de Investigación y Posgrado, Unidad de Biomedicina, Facultad de Estudios Superiores Iztacala, Universidad Nacional \\ Autónoma de México, Tlalnepantla, México \\ Email: *dianacecitapia@hotmail.com
}

How to cite this paper: Carapia-Fierros, $P$. and Tapia-Pancardo, D.C. (2021) Innovative Techniques to Develop Educative Competitiveness in Adolescents' Mental Health: Importance in Nursing Training. Health, 13, 903-909.

https://doi.org/10.4236/health.2021.139069

Received: August 7, 2021

Accepted: August 29, 2021

Published: September 1, 2021

Copyright $\odot 2021$ by author(s) and Scientific Research Publishing Inc. This work is licensed under the Creative Commons Attribution International License (CC BY 4.0).

http://creativecommons.org/licenses/by/4.0/

\begin{abstract}
Background: The challenge for nursing training highlights the priorities for knowing and attending current educational tendencies on adolescents and the university curriculum, required for a nurse professional to develop skills to reach success in health education. The aim was to establish the importance of nurse training by using innovative techniques to develop skills in adolescent mental health education. Methods: Qualitative and descriptive research with an exploratory approach. Six nurse students of 20 - 25 years of age, both sexes, were invited to participate in a public university setting. Immersion tools were implemented such as, testimony, hexagrams, interactive didactic materials, all of them previously validated by expert judges. Data collection was through a semi-structured interview, after a signed informed consent letter. Results: Five categories emerged, Category I. Innovative educational strategies, like immersion tools; Category II. Innovative strategy to treat complex topics; Category III. Innovative techniques that favor health education; Category IV. Importance of upgrading nurse professionals; Category V. Importance of Innovative mental health education for adolescents. Conclusions: Nursing training with innovative techniques to develop skills in mental health for adolescents requires better educational, research and evaluation methods to fulfill professionals training, to provide a better health education in adolescents, and to reach a significant learning.
\end{abstract}

\section{Keywords}

Nurse Education, Adolescents, Mental Health, Innovative Techniques 


\section{Introduction}

The challenge for nurses' education, since they are the early contact with children and adolescents, highlights the priorities for knowing and attending current educational tendencies around modern education in adolescents, and the university curriculum [1]. Nursing education must be the basis for continuous learning, as well as teaching and must seek flawless opportunities for entering graduate programs, required for a nurse professional to develop skills to reach success in health education [2]. Nursing profession gathered pedagogic innovative (technologic) models, to promote successful significant learning and help to grow as critic and analytic individuals [2] [3] [4]. It is necessary to change the educational model that yields a passive student along with the authority and power image of the teacher, as the one who possesses knowledge to one that incentivizes responsibility and student centered learning according to his/her reality, i.e., a radical transformation in nurse education [5] [6]. The aim was to establish the importance of nurse training by using innovative techniques to develop skills in adolescent mental health education, since an early intervention improves youngsters' prevention for risks such as violence, drugs, and alcohol abuse [3] [7].

\section{Methods}

Qualitative research with an exploratory and descriptive approach was conducted, it proposed participants to share their experiences and opinions [8]. Six nurse students from $4^{\text {th }}$ and $5^{\text {th }}$ semesters, attending the module Attention to Addictions in Health Area, aged 20 - 25 years, both sexes were the informants; the setting was a public university in the State of Mexico. Immersion tools such as testimonials, hexagrams, and didactic interactive materials were implemented, which were previously valued by experts' judges [9] [10] [11] [12]. The innovative tools were used for the training of the students in the module, as future promoters of health. Data collection was through semi-structured interview using 4 guided questions, the backup of data was by using a voice recording device that registered conversations which lasted about 1 hour in each case [13]. Data analysis was according to Souza Minayo, transcription of answers and dialogues and descriptive analysis (categorization of answers) from guided questions [14].

\section{Ethics and Legal Aspects}

Ethics and legal aspects were based on the principles of the Declaration of Helsinki, point 6 "the right to safeguard the integrity of persons must always be respected. All needed precautions must be adopted to respect intimacy of persons, reduce to a minimum the impact of the study on their physical, mental and personality". An informed consent letter was signed by each informer according to the Nüremberg code and local law. 


\section{Results}

Five categories emerged each with sub-categories.

Category I. Innovative educational strategies: immersion tools; sub-category 1.1: to favor the process to show, to know, to comprehend, to explain and to synthesize.

Category II. Innovative strategy to approach complex topics; sub-category 2.1: tempting for to handle the drug abuse, it invites to have critical, analytical and reflexive thinking.

Category III. Innovative techniques to favor health education; sub-category 3.1: to favor appropriation of the message and the risk perception.

Category IV. Importance of nurse professional updating; sub-category 4.1: Traditional vs. New School, cutting innovation, continuous education.

Category V. Importance of innovative education for the adolescent mental health; sub-category 5.1: to favor significant learning and self-care (Table 1).

\section{Discussion}

Educational strategy refers to a set of mental activities that a subject employs in an instructional situation to facilitate knowledge acquisition [13]. An immersion tool is a didactic resource that facilitates the teaching-learning process, improving students to acquire better skills for a determined content, and allowing them to organize and synthesize information in an easy, recreational, funny and spontaneous ways, in order to be assimilated and remembered due to the interest for the content which favors the development of abilities [15]. That is coincident with Category I, Innovative educational strategies: immersion tools and sub-category 1.1: to favor the process to show, to know, to comprehend, to explain and to synthesize.

[...] These are innovative didactic strategies that will help us to acquire better knowledge and to comprehend and synthesize some topics that are new and complex for us. $\mathbf{5} 5$

Table 1. Emerged categories.

\begin{tabular}{ll}
\hline \multicolumn{1}{c}{ Categories } & \multicolumn{1}{c}{ Sub-categories } \\
\hline $\begin{array}{l}\text { Category I, Innovative educational strategies: } \\
\text { immersion tools. }\end{array}$ & $\begin{array}{l}\text { 1.1. To favor the process to show, to know, } \\
\text { to comprehend, to explain and to synthesize. }\end{array}$ \\
$\begin{array}{l}\text { Category II, Innovative strategy to approach } \\
\text { complex topics. }\end{array}$ & $\begin{array}{l}\text { 2.1. Tempting for to handle the drug abuse, } \\
\text { it invites to have critical, analytical and } \\
\text { reflexive thinking. }\end{array}$ \\
$\begin{array}{l}\text { Category III, Innovative techniques to favor } \\
\text { health education. }\end{array}$ & $\begin{array}{l}\text { 3.1. To favor appropriation of the message } \\
\text { and the risk perception. }\end{array}$ \\
$\begin{array}{l}\text { Category IV, Importance of nurse } \\
\text { professional updating. }\end{array}$ & $\begin{array}{l}\text { 4.1. Traditional vs. New School, cutting } \\
\text { innovation, continuous education. }\end{array}$ \\
$\begin{array}{l}\text { Category V, Importance of innovative } \\
\text { education for the adolescent mental health. }\end{array}$ & 5.1. To favor significant learning and self-care. \\
\hline
\end{tabular}

Source: students attending the module attention to addictions in health area, state of Mexico, 2019. 
The strategies involve all approaches and ways of doing that allow teachers to lead with expertise students' learning. These are instruments that teachers make the most of to reach significant learning in students, which must be used to encourage adolescents to obtain the proposed goal. Therefore, didactic strategies establish actions for students to be interested, and then attain their creativity to interact with teachers, materials and media searching for significant knowledge [9] [12]. The nurse will catch up the adolescent through science and technology, to educate and prevent risks that adolescent faces and that could be preventable [9] [12] [15], as seeing in Category II, Innovative strategy to approach complex topics; sub-category 2.1: tempting for to handle the drug abuse, it invites to have critical, analytical and reflexive thinking.

[...] I think these are strategies for teaching-learning that show better, by using images and schemes, and avoid the use of many words since these distract the attention of adolescents and, at the same time, these materials invite to a critical, analytical and reflexive thinking in the adolescent. S3

Perception and interpretation of the presented information will depend of individual's previous experience, as well as its personal interest and its interpretation with other persons. A perceptive process will exist through which the individual selects, organizes and interpret the stimuli to better adapt them for comprehension; finally, this process leads to a critical, analytical and reflexive thinking which favors the informed and assertive decisions taking, on the contrary to negative decisions related to its event's risk perception [16] [17] [18] [19] [20]. If the student interacts by using a tempting ICT that captures its attention, and make them to relate the information with their daily life and the possible consequences. As observed in Category III. Innovative techniques to favor health education; sub-category 3.1: to favor appropriation of the message and the risk perception.

[...] The hexagram and testimonials are new learning strategies that will help us to favor health education in adolescents; testimonial is more real, and makes that messages reach the person, since the way they tell makes you feel what they experienced and pulls you into their stories, seeing the many risks they face because no one is exempt of this kind of situations. S2

[...] The most significant strategies that I will use in health education are the videos and games, since they are helpful, attractive and fun; if you invite them to play with information lead to their learning, to have fun, and the videos make them to relate the information with their daily life. S5

Nursing faces the challenge to get over the stratification of traditional school which has a pedagogy based in formalism and memorization, and in authoritarianism and discipline; however, in opposition the new school shows innovation in education that vindicates significance and values, and is centered in the adolescent spontaneous interests and aspires to strength its activity, liberty and autonomy, which results in significant learning that helps to modify its daily behavior [3] [6]. Globalization with its enormous changes led to face the challenge 
for better education, which requires a transforming action that contributes to development [7] [21]. To think in an educational proposal that teaches to "learn how to learn" it is necessary to seek a change not only educational, but also in policy, economy, social, ecology, spiritual and cultural, that permit comprehension of reality [19] [22]. As observed in Category IV, Importance of nurse professional updating; sub-category 4.1: Traditional vs. New School, cutting innovation, continuous education.

[...] Most of nurse staff is not in the forefront and all staff, from new to old classes must be upgraded, since nurses kept the knowledge they learned years ago; it is necessary to have continuous education to be better in our profession, and the message to adolescents reaches them as desired. S1

Along nurse training learning involves a construction and reconstruction process where each student input has a decisive role, and confer sense to what is learned with their reality, i.e., what is learned will be re-enacted in its scenarios. It is a dynamic, individual and social process in which knowledge is constructed, values, attitudes, skills and abilities are developed; they get accommodated and new knowledge schemes are reorganized to allow students comprehend, reconstructing, and face reality developing capabilities by means of technology as a tool [9] [19] [22]. As observed in Category V, Importance of innovative education for the adolescent mental health; sub-category 5.1: to favor significant learning and self-care.

[...] It is important that us, as health professionals, be immersed in adolescent mental health education with innovation; we could help adolescents to face their challenges, so that they have better information as well as we can enter that dynamic topics, because we are not immersed, i.e., that we have continuous upgrading and participation. $\mathbf{S 2}$

To organize the teaching-learning process in a currently changing world is an uncertainty task for educators. It is a complex task that recognizes that teachers must know when, where and why they use those teaching strategies, always considering the features to whom information is directed [6] [23].

\section{Conclusion}

The importance of nurse training with innovative techniques to develop professional competence in education for mental health in adolescents, is based on the constant pressure of economic, technologic, and social demands during this step of life. To attend them it is necessary to have adequate educational, investigative and evaluation methods, which allow improving the urgent requirements for professional training; if so, they will give a better health education for adolescents, since a globalized world claims for innovative and upgraded staff in new pedagogic technologies, seeking significant learning.

\section{Acknowledgements}

Authors thank PAPIME 300920, DGAPA, UNAM for funding. 


\section{Conflicts of Interest}

The authors declare no conflicts of interest regarding the publication of this paper.

\section{References}

[1] Fawaz, M.A., Hamdan-Mansour, A.M. and Tassi, A. (2018) Challenges Facing Nursing Education in the Advanced Healthcare Environment. International Journal of Africa Nursing Sciences, 9, 105-110. https://doi.org/10.1016/j.ijans.2018.10.005

[2] Safriet, B. (2011) Federal Options for Maximizing the Value of Advanced Practice Nurses in Providing Quality, Cost-Effective Health Care. In: The Future of Nursing: Leading Change, Advancing Health, The National Academies Press, Washington DC, 443-476.

[3] Baron, K.A. (2017) Changing to Concept-Based Curricula: The Process for Nurse Educators. The Open Nursing Journal, 11, 277-287. https://doi.org/10.2174/1874434601711010277

[4] Sánchez, A. (2014) Educational Flows That Have Permeated the Nursing Education in the National School of Nursing and Midwifery. Revista de enfermería neurológica, 13, 95-98. (In Spanish)

[5] Rosseter, R. (2019) The Impact of Education on Nursing Practice. AACN. The Voice of Academic Nursing, (202) 463-6930.

[6] Tapia, D. (2019) Health Care in Nursing: Theoretical and Pedagogic Basis. National Autonomous University of Mexico, Mexico City. (In Spanish)

[7] Mcallister, M. (2019) Nurses Need to Step Up to Improve Child and Adolescent Mental Health Globally. Contemporary, 55, 275-277. https://doi.org/10.1080/10376178.2019.1681901

[8] Hernández, S.R., Fernández, C.C. and Baptista, L.M. (2013) Methodology of Investigation. PENSO.

[9] Tapia, D., Villalobos, R., Ostiguín, R., Cadena, J. and Ramírez, J. (2018) Education, Technology and Health for Adolescents: Models of Thinking, Learning, Emotions and Prevention of Use and Abuse of Addictive Substances. National Autonomous University of Mexico, Mexico City. (In Spanish)

[10] Tapia, D., Padilla, J., Carapia, P., Ramírez, D., Ibarra, M. and Villalobos, R. (2018) Development of Emotional Intelligence in Early Adolescence to Prevent Bullying and Drug Use. Paraninfo Digital, 12, e006. (In Spanish)

http://www.index-f.com/para/n28/e006.php

[11] Venger, O. (2017) Internet Research in Online Environments for Children: Readability of Privacy and Terms of Use Policies; the Uses of (Non)personal Data by Online Environments and Third-Party Advertisers. Journal of Virtual Worlds Research, 10, 2-15. https://doi.org/10.4101/jvwr.v10i1.7227

[12] Percastegui, I. and Tamayo, D. (2014) Comparison of Mental Maps and Hexagrams with Real Testimonials Use as a Learning Strategy to Prevent Addictions in Secondary School of Nezahualcóyotl Municipality. National Autonomous University of Mexico, Mexico City. (In Spanish)

https://repositorio.unam.mx/contenidos/comparacion-de-mapas-mentales-y-hexag ra-

mas-con-el-uso-de-testimonio-real-como-estrategia-de-aprendizaje-para-la-preven$\underline{4}$

[13] Thomas, L. (2017) Nursing Children and Young People: What Mental Health Train- 
ing Is Required? British Journal of Nursing, 26, 234-237.

https://doi.org/10.12968/bjon.2017.26.4.234

[14] De Souza, M.C., Ferreira, Deslandes, S. and Gomes, R. (2016) Pesquisa Social. Teoria, Método e Criatividade. Vozes.

https://wp.ufpel.edu.br/franciscovargas/files/2012/11/pesquisa-social.pdf

[15] Rosales, S.D. and López, B. (2018) Immersion Tools and Emotional Intelligence as a Didactic Strategy to Develop Assertive Behaviors in Adolescents. National Autonomous University of Mexico, Mexico City. https://repositorio.unam.mx/contenidos/396211

[16] Ennett, S.T., Haws, S., Ringwalt, C.L., Vincus, A.A., Hanley, S., Bowling, J.M. and Rohrbac, L.A. (2011) Evidence-Based Practice in School Substance Use Prevention: Fidelity of Implementation under Real-World Conditions. Health Education Research, 26, 361-371. https://doi.org/10.1093/her/cyr013

[17] Gutiérrez-Martínez, J., Martínez-Mondragón, R., Rivera-Ramírez, C., Piñón-Atilano, C., Hernández-Bravo, W., Navarrete-Mejorada, A., Sánchez-Gómez, V. and TapiaPancardo, D. (2020) Immersion Tools as a Strategy for Adolescents Mental Health: A Qualitative Study. Health, 12, 866-875.

https://doi.org/10.4236/health.2020.127064

[18] Caltenco, R. and García, J. (2017) Development of Emotional Intelligence through Immersion Tools to Prevent Addiction and Bullying in Adolescents. National Autonomous University of Mexico, Mexico City. (In Spanish) https://repositorio.unam.mx/contenidos/397118

[19] Ferreri, F., Bourla, A., Mouchabac, S. and Karila, L. (2018) e-Addictology: An Overview of New Technologies for Assessing and Intervening in Addictive Behaviors. Frontiers in Psychiatry, 9, 51. https://doi.org/10.3389/fpsyt.2018.00051

[20] Tapia-Pancardo, D., Rosales-Rodríguez, S., López-Moreno, B. and Ibarra-González, M. (2018) Digital Tools Contributions to Prevent Addictions in Nursing Students. Journal of Education, Society and Behavioural Science, 25, 1-9. https://doi.org/10.9734/JESBS/2018/41873

[21] Le Donné, N., Fraser, P., Bousquet, G. and OECD (2016) Teaching Strategies for Instructional Quality: Insights from the TALIS-PISA Link Data.

[22] Belias, D., Sdrolias, L., Kakkos, N., Koutiva, M. and Koustelios, A. (2013) Traditional Teaching Methods vs. Teaching through the Application of Information and Communication Technologies in the Accounting Field: Quo vadis? European Scientific Journal, 9, 73-101.

[23] Acevedo-Peña, M., Ostiguín-Meléndez, R., Cadena-Anguiano, J., Ibarra-Gonzalez, M., Hernández-Hernández, J., Villalobos-Molina, R. and Tapia-Pancardo, D. (2021) Problem-Based Learning in Situ Applied to Students in the Assessment of Nursing Process. Open Journal of Nursing, 11, 378-389.

https://doi.org/10.4236/ojn.2021.115033 